\title{
M. Kundić*
}

\section{ODGOVORNOST ZA ŠTETU NASTALU U OBAVLJANJU VATROGASNE DJELATNOSTI}

UDK 614.842

PRIMLJENO: 21.9 .2020$.

PRIHVAĆENO: 19.4 .2021

Ovo djelo je dano na korištenje pod Creative Commons Attribution 4.0 International License

SAŽETAK: Obavljanje vatrogasne djelatnosti podrazumijeva zakonitu primjenu javnih ovlasti u izvršavanju vatrogasnih intervencija. Prekoračenje javnih ovlasti ili druga nezakonita postupanja u sklopu obavljanja vatrogasne djelatnosti mogu uzrokovati nastanak štete trećim osobama. Odgovornost vatrogasnih postrojbi i organizacija obilježava odnos odgovornosti za štetu koju počine zaposlenici, odnosno njihovi članovi. Iz perspektive vatrogasaca s druge strane, odgovornost za nadoknadu štete nastale u obavljanju vatrogasne djelatnosti može se razmatrati na dvije razine. Jedna razina obuhvaća odgovornost za štetu koju vatrogasac trećim osobama počini u obavljanju ili prilikom obavljanja vatrogasne službe te druga razina koja obuhvaća odgovornost vatrogasca za štetu koju namjerno ili krajnjom nepažnjom nanese Republici Hrvatskoj ili jedinici lokalne i područne (regionalne) samouprave, odnosno vatrogasnoj postrojbi u kojoj radi ili djeluje u vezi s obavljanjem vatrogasne djelatnosti. Novim Zakonom o vatrogastvu koji je na snagu stupio 1. siječnja 2020. godine detaljnije je regulirano pitanje odgovornosti za štetu nastalu u obavljanju vatrogasne djelatnosti. U radu se razmatra zakonska osnova odgovornosti za štetu nastalu u sklopu obavljanja vatrogasne djelatnosti te pregled izmjena na temelju novog Zakona o vatrogastvu.

Ključne riječi: vatrogasna služba, zaštita od požara, nadoknada štete, javne ovlasti

\section{UVOD}

Obavljanje vatrogasne djelatnosti obilježava povećana mogućnost nastanka štete trećim osobama. Sam nastanak štete, uz ispunjenje ostalih pretpostavki odgovornosti za štetu, predstavlja osnovu potencijalne građansko pravne materijalne odgovornosti za popravljanje nastale štete.

Na temelju ranijeg Zakona o vatrogastvu koji je bio na snazi do 1. siječnja 2020. godine ${ }^{1}$, pitanje odgovornosti za nadoknadu štete u obavljanju vatrogasne djelatnosti nije bilo zasebno regulirano te su za prosudbu iste bile mjerodavne opće odredbe o odgovornosti za štetu na temelju Zako-

\footnotetext{
*Marin Kundić, dipl. iur., (marin.kundic@vuka.hr), Veleučilište u Karlovcu, Trg J.J. Strossmayera 9, 47000 Karlovac.

'Zakon o vatrogastvu (N.N., br. 106/99., 117/01., 36/02., 96/03., 139/04. - pročišćeni tekst, 174/04., 38/09. i 80/10.).
}

na o obveznim odnosima ${ }^{2}$ i primjenjivih odredbi Zakona o radu. ${ }^{3}$ Navedene odredbe biti će mjerodavne i prema pozitivno pravnom uređenju u slučaju kada novim Zakonom o vatrogastvu određeno pitanje nije drugačije regulirano.

Na temelju Zakona o vatrogastvu ${ }^{4}$ koji je na snagu stupio 1. siječnja 2020. godine, pitanje odgovornosti za štetu nastalu u obavljanju vatrogasne djelatnosti uređeno je izrijekom na osnovi odredbi čl. 71. do 75. Zakona. U radu se razmatra opći kontekst odgovornosti za štetu nastalu u obavljanju vatrogasne djelatnosti, kao i doseg izmjena prema novom Zakonu o vatrogastvu.

${ }^{2}$ Zakon o obveznim odnosima (N.N., br. 35/05., 41/08., 125/11., 78/15., 29/18., dalje u tekstu: ZOO).

${ }^{3}$ Zakon o radu (N.N., br. 93/14., 127/17., 98/19.).

${ }^{4}$ Zakon o vatrogastvu (N.N., br. 125/19.). 


\section{PRAVNI OKVIR ODGOVORNOSTI ZA ŠTETU}

Obavljanje vatrogasne djelatnosti podrazumijeva mogućnost uzrokovanja štete trećim fizičkim i pravnim osobama nastale u obavljanju vatrogasne intervencije ili općenitom obavljanju vatrogasne djelatnosti. S obzirom da do stupanja novog Zakona o vatrogastvu pitanje odgovornosti za štetu nastalu u obavljanju vatrogasne djelatnosti nije bilo zasebno pravno regulirano, za utvrđivanje odgovornosti za štetu bile su mjerodavne opće odredbe obveznog prava o odgovornosti za štetu i primjenjive odredbe Zakona o radu. Pri tome će izloženi kontekst pravne odgovornosti biti primjenjiv i prema novom Zakonu o vatrogastvu ako istim nije nešto drugo određeno.

Odgovornost vatrogasnih postrojbi i organizacija obilježava odnos odgovornosti za štetu koju počine zaposlenici, odnosno njihovi članovi. S druge strane, odgovornost vatrogasaca kao osoba koje obavljaju vatrogasnu djelatnost može se razmatrati na dvije razine, i to odgovornosti za štetu koju vatrogasac uzrokuje trećim osobama, ali i potencijalnoj odgovornosti vatrogasca za štetu koja je na temelju štetnog događaja nastala Republici Hrvatskoj ili jedinici lokalne i područne (regionalne) samouprave, odnosno vatrogasnoj postrojbi u kojoj radi ili djeluje u svezi s obavljanjem vatrogasne djelatnosti.

Za nastanak odgovornosti za štetu potrebno je, u pravilu, kumulativno ispunjenje pretpostavki odgovornosti za štetu, pri čemu su potrebne pretpostavke:

1. subjekti,

2. štetna radnja,

3. šteta,

4. uzročna veza i

5. protupravnost.

U nastavku rada razmatraju se pretpostavke odgovornosti za nastanak štete u specifičnom području obavljanja vatrogasne djelatnosti.

\section{Odgovornost vatrogasnih postrojbi i vatrogasnih organizacija}

Odgovornost vatrogasnih postrojbi i vatrogasnih organizacija prema trećim osobama obi- lježava institut odgovornosti za drugoga. Prema Zakonu o obveznim odnosima, za štetu koju zaposlenik u radu ili u svezi s radom prouzroči trećoj osobi odgovara poslodavac kod kojega je radnik radio u trenutku prouzročenja štete, osim ako dokaže da su postojali razlozi koji isključuju odgovornost zaposlenika. ${ }^{5}$

Odgovornost vatrogasnih postrojbi i vatrogasnih organizacija kao poslodavca, dakle, neposredno je povezana s postupanjem vatrogasaca, kao zaposlenika, u konkretnim okolnostima svakog pojedinačnog slučaja. U obavljanju poslova iz svoje profesionalne djelatnosti, vatrogasci su dužni postupati s povećanom pažnjom, prema pravilima struke i običajima, odnosno, primjenom kriterija pažnje dobrog stručnjaka.

Poslodavac će za štetu odgovarati u slučaju kada radnik nije postupao pažnjom dobrog stručnjaka. S obzirom da nepostupanje s pažnjom koja se zahtijeva treba smatrati skrivljenim ponašanjem, riječ je o odgovornosti kod koje je krivnja zaposlenika odlučujuća pretpostavka te je stoga riječ o subjektivnoj odgovornosti.

Krivnja se javlja u dva oblika, kao namjera (dolus) i nepažnja (culpa). Namjera (dolus) je takva vrsta krivnje kod koje se zahtijeva da je štetnik postupao znajući i hotimice. Kod nepažnje se razlikuju dva stupnja krivnje - krajnja i obična nepažnja. S krajnjom nepažnjom (culpa lata) postupa onaj štetnik koji u svojem ponašanju ne upotrijebi niti onu pažnju koju bi upotrijebio svaki prosječni čovjek, dok s običnom nepažnjom (culpa levis) postupa onaj štetnik koji u svojem ponašanju ne primijeni onu pažnju koju bi upotrijebio osobito pažljiv i savjestan čovjek (pažnja dobrog domaćina). Pri tome se predmnijeva obična nepažnja. ${ }^{6}$

To, međutim, ne znači da nije moguća i objektivna odgovornost vatrogasnih postrojbi i vatrogasnih organizacija u slučaju kad je šteta prouzročena opasnom stvari ili opasnom djelatnošću. ${ }^{7}$

${ }^{5}$ Također, prema odredbi čl. 1062. ZOO-a, pravna osoba odgovara i za štetu koju njezino tijelo prouzroči trećoj osobi u obavljanju ili u vezi s obavljanjem svojih funkcija. Ako za određeni slučaj nije što drugo u zakonu određeno, pravna osoba ima pravo na naknadu od osobe koja je štetu skrivila namjerno ili krajnjom nepažnjom.

${ }^{6}$ Čl. 1045., st. 2. ZOO-a.

${ }^{7}$ Vedrišs, M., Klarić, P.: Građansko pravo, Opći dio, stvarno, obvezno i nasljedno pravo, peto izdanje, Narodne novine, Zagreb, 2001., str. 581. 
Kod ovog oblika odgovornosti ne traži se krivnja štetnika.

Pravila objektivne odgovornosti primjenjuju se na štete od opasne stvari i djelatnosti ${ }^{8}$ te na štete u drugim slučajevima propisanim zakonom. ${ }^{9}$ Zakon o obveznim odnosima ne sadrži definiciju opasne stvari, već je sudskoj praksi ostavljena ocjena hoće li neka određena stvar ili djelatnost u konkretnom slučaju biti kvalificirana kao opasna.

Pod opasnom stvari razumijeva se svaka stvar koja po svojoj namjeni, osobinama, položaju, mjestu i načinu uporabe ili na drugi način predstavlja povećanu opasnost nastanka štete za okolinu pa je zbog toga treba nadzirati povećanom pažnjom. Djelatnost predstavlja povećanu opasnost kada u njezinom redovnom tijeku, već po samoj njezinoj tehničkoj prirodi i načinu mogu biti ugroženi životi i zdravlje ljudi ili imovina, tako da to ugrožavanje iziskuje povećanu pozornost osoba koje obavljaju tu djelatnost kao i osoba koje s njom dolaze u dodir. ${ }^{10}$

Upravo je vatrogastvo djelatnost koju u značajnom dijelu obilježavaju radnje i uporaba sredstava koje se u značajnom dijelu mogu karakterizirati kao povećana opasnost za okolinu. ${ }^{11}$

\section{Odgovornost vatrogasaca}

Postupanje vatrogasaca prilikom nastanka štetnog događaja bit će pretpostavka određivanja odgovornosti pravnih osoba vatrogasnih postrojbi i vatrogasnih organizacija za odgovornost za štetu trećim osobama. S druge strane, oštećenik popravljanje štete samo iznimno ima pravo zahtijevati neposredno od vatrogasca ako je štetu prouzročio namjerno. ${ }^{12}$

\footnotetext{
${ }^{8}$ Čl. 1045., st. 3. ZOO-a.

${ }^{9}$ Čl. 1045., st. 4. ZOO-ᄀa.

${ }^{10}$ Vedriš, M., Klarić, P.: Građansko pravo, Opći dio, stvarno, obvezno i nasljedno pravo, peto izdanje, Narodne novine, Zagreb, 2001., str. 576 .

${ }^{11}$ Prema sudskoj praksi, opasnim stvarima smatraju se npr. motorno vozilo u pokretu, posude pod tlakom, eksplozivi, dizala, razni strojevi na motorni ili električni pogon i dr.
}

Također, i u kontekstu općeg uređenja instituta izvanugovorne odgovornosti za štetu, ali i na temelju odredbi Zakona o radu, poslodavac koji je oštećeniku popravio štetu ima pravo od zaposlenika potraživati nadoknadu ako je šteta uzrokovana namjerno ili iz krajnje nepažnje. $U$ navedenom smislu, odgovornost vatrogasca prema poslodavcu šira je od odgovornosti prema trećim osobama.

Na osnovi izloženih odredbi odgovornosti za štetu, vatrogasne postrojbe odgovarale su i ranije za štetu koju vatrogasac uzrokuje u obavljanju vatrogasne intervencije, dok je vatrogasac za štetu koju je nadoknadila vatrogasna postrojba također odgovarao jedino u slučaju kada je ista počinjena s namjerom ili zbog krajnje nepažnje. Proširenjem odgovornosti prema novom Zakonu o vatrogastvu na jedinice lokalne i područne samouprave i Republiku Hrvatsku, otvorena je i mogućnost regresne odgovornosti vatrogasca za štetu počinjenu u obavljanju vatrogasne djelatnosti prema navedenom krugu subjekata.

\section{Doseg izmjena prema novom Zakonu o vatrogastvu}

\section{Proširenje odgovornosti za nadoknadu štete trećim osobama}

Uzevši u obzir zakonsko uređenje odgovornosti poslodavaca za štetu koju u obavljanju poslova radnog mjesta uzrokuje zaposlenik, za razmatranje dosega izmjena pravnog uređenja u odnosu na ranije uređenje u sklopu općih odredbi obveznog prava, nužno je definiranje pravnog oblika vatrogasnih postrojbi i organizacija u svrhu utvrđivanja primjenjive odgovornosti osnivača.

Javne vatrogasne postrojbe osniva jedinica lokalne samouprave na temelju Zakona o ustanovama te jedinice lokalne samouprave kao osnivači solidarno i neograničeno odgovaraju za obveze ustanove..$^{13}$

S druge strane, postrojbe dobrovoljnog vatrogasnog društva i postrojbe dobrovoljnog vatroga-

${ }^{12}$ Čl. 1061., st. 1. i 2. ZOO-a

${ }^{13}$ Čl. 59., st. 2. Zakona o ustanovama (N.N., br. 76/93., 29/97., 47/99., 35/08., 127/19.). 
snog društva u gospodarstvu te vatrogasne zajednice osnivaju se i djeluju na temelju Zakona o udrugama. Za svoje obveze udruga odgovara cijelom svojom imovinom, dok članovi udruge i članovi njezinih tijela ne odgovaraju za obveze udruge. ${ }^{14}$

Profesionalna vatrogasna postrojba $\mathrm{u}$ gospodarstvu osniva se kao ustrojstvena jedinica ili kao društvo u većinskom vlasništvu osnivača. U slučaju da je trgovačko društvo osnovano kao društvo kapitala, osnivači u kontekstu općih odredbi prava društava neće odgovarati za obveze društva. ${ }^{15}$

Prema novom Zakonu o vatrogastvu izravno je propisana odgovornost jedinica lokalne i područne samouprave i Republike Hrvatske za štetu koju vatrogasac počini trećim osobama u obavljanju vatrogasne službe ovisno o tome je li šteta počinjena na vatrogasnoj intervenciji državne, županijske ili lokalne razine. ${ }^{16}$

U skladu s ranijim pravnim uređenjem za štetu koju u obavljanju vatrogasne djelatnosti počini vatrogasac bila je propisana odgovornost pravnih osoba u sklopu kojih djeluju vatrogasne postrojbe, dok bi se u smislu solidarne i neograničene odgovornosti osnivača u skladu s izloženim pravnim oblikom primjenjivala izravna odgovornost gradova i općina kao jedinica lokalne samouprave jedino u odnosu na štetu koju počine pripadnici javnih vatrogasnih postrojbi. Novim Zakonom o odgovornosti je na temelju uspostavljanja izravne odgovornosti jedinica lokalne i područne samouprave te Republike Hrvatske, ovisno o razini obavljanja intervencije, došlo do faktičnog proširenja odgovornosti za nadoknadu štete nastale u obavljanju vatrogasne djelatnosti.

Također, u kontekstu opće odgovornosti za nadoknadu štete, za štetu koju prilikom obavljanja vatrogasne intervencije nastane uporabom opasne stvari prilikom obavljanja vatrogasne djelatnosti odgovorne su pravne osobe vatrogasnih postrojbi, dok je na temelju novog Zakona o vatrogastvu institut izrijekom proširen i na je-

${ }^{14}$ Čl. 1061., st. 1. i 2. ZOO-a.

${ }^{15}$ Čl. 59., st. 2. Zakona o ustanovama (N.N., br. 76/93., 29/97., 47/99., 35/08., 127/19.).

${ }^{16}$ Čl. 72. Zakona o vatrogastvu (N.N., br. 125/19.). dinice lokalne i područne samouprave te Republiku Hrvatsku.

\section{Javne ovlasti}

Javne ovlasti vatrogasne postrojbe izrijekom su predviđene kao razlog oslobođenja od odgovornosti za nadoknadu štete. Primjena javnih ovlasti kriterij je oslobođenja odgovornosti pravnih osoba vatrogasnih postrojbi, jedinica lokalne i područne samouprave te Republike Hrvatske u sklopu razmatranja postupanja vatrogasca $u$ intervenciji u čijem obavljanju je trećoj osobi nastala šteta. Jednako tako, primjena javnih ovlasti odnosi se i na utvrđivanje odgovornosti vatrogasca te iako je radnja koja je uzrokovala štetu trećoj osobi počinjena s namjerom (npr. uništenje tuđe stvari u sklopu vatrogasne intervencije) u slučaju nastanka štete koja je posljedica primjene javnih ovlasti nema odgovornosti za štetu.

U sklopu ranijeg uređenja za određivanje odgovornosti za nadoknadu štete potencijalno nastale primjenom javnih ovlasti u obavljanju vatrogasne intervencije mjerodavne su bile odredbe o isključenju odgovornosti zbog krajnje nužde.

Kod krajnje nužde osoba čini štetnu radnju da bi od sebe ili drugoga otklonila istodobnu neskrivljenu opasnost koja se na drugi način nije mogla otkloniti, a pritom je zlo koje je učinjeno manje od onoga koje je prijetilo.

Šteta počinjena u stanju nužde, što odgovara opsegu instituta primjene javnih ovlasti u obavljanju vatrogasne intervencije, razlog je oslobođenja odgovornosti koji otklanja odgovornost od osobe koja je neposredno počinila štetnu radnju. U navedenom slučaju, oštećenik ima pravo potraživanja štete od osobe koja je kriva za nastanak opasnosti štete, kao i od osoba od kojih je šteta otklonjena, ali ne više od koristi koje su imale od otklanjanja štete. ${ }^{17}$

\footnotetext{
${ }^{17}$ Primjerice, rušenje građevina preko kojih bi se požar mogao proširiti, ako se širenje požara ne može spriječiti na drugi način, nedvojbeno će uzrokovati štetu vlasnicima objekta, ali s obzirom da je šteta počinjena primjenom instituta javnih ovlasti u obavljanju vatrogasne intervencije, za nadoknadu štete neće odgovarati vatrogasci koji su obavljali vatrogasnu intervenciju, nego osobe koje su uzrokovale nastanak požara ili drugog štetnog događaja koji je uzrokovao vatrogasnu intervenciju.
} 
Institut krajnje nužde ostat će mjerodavan za prosudbu odgovornosti za nadoknadu štete u širem kontekstu koji u sklopu vatrogasnih intervencija ne obuhvaća taksativno određenje javnih ovlasti vatrogasnih postrojbi u obavljanju vatrogasne intervencije. Ipak, izravno zakonsko reguliranje primjene instituta javnih ovlasti kao razloga oslobođenja od odgovornosti sigurno će ukloniti mnoge nedoumice u sudskoj praksi.

\section{Stegovni postupak i utvrđivanje materijalne odgovornosti}

Vatrogasac će za štetu koja je u sklopu obavIjanja vatrogasne intervencije počinjena jedinici lokalne i područne samouprave te Republike Hrvatske biti odgovoran u slučaju kada je ista nanesena namjerom ili krajnjom nepažnjom.

Zakonom je određeno da će se o nadoknadi štete koju vatrogasac u obavljanju djelatnosti počini Republici Hrvatskoj ili jedinici lokalne i područne (regionalne) samouprave odnosno vatrogasnoj postrojbi u kojoj radi ili djeluje odlučivati u stegovnom postupku u povodu teže povrede obveza iz radnog odnosa.

Utvrđivanje stegovne odgovornosti u navedenom postupku osnova je utvrđivanja građanskopravne materijalne odgovornosti za nadoknadu štete, dok će u navedenom postupku morati biti dokazano i postojanje šireg kruga pretpostavki za osnovanost zahtjeva za nadoknadu štete.

\section{Dodatni razlozi za oslobođenje od odgovornosti}

Kao dodatni razlozi oslobođenja od odgovornosti predviđeni su počinjenje štete po nalogu nadređenog rukovoditelja ili uzrokovanje štete krajnjom nepažnjom zbog znatnih napora u obavljanju vatrogasne djelatnosti ili pod okolnostima kada je štetu bilo teško izbjeći.

Vatrogasac se može u cijelosti ili dijelom osloboditi odgovornosti za nastalu štetu ako je do nje došlo postupanjem po nalogu uz uvjet da je prethodno pisano ili usmeno upozorio nadređenog rukovoditelja odnosno zapovjednika da će provedbom naloga nastati ili da bi mogla nastati šteta.
Oslobođenje od odgovornosti za nastanak štete do koje je došlo krajnjom nepažnjom zbog znatnih napora ili pod posebnim okolnostima usmjeren je prema uvažavanju specifičnosti obavljanja vatrogasne djelatnosti koje su mogle dovesti do nastanka štetnog događaja.

Postupak utvrđivanja postojanja razloga oslobođenja odgovornosti provodi povjerenstvo od tri člana koje imenuje glavni vatrogasni zapovjednik, a konačnu odluku donosi glavni vatrogasni zapovjednik.

\section{ZAKLJUČAK}

Specifičnosti obavljanja vatrogasne djelatnosti pretpostavljaju mogućnost nastanka štete trećim osobama. Razmatrajući institut odgovornosti za štetu, vatrogasac će za štetu koja je trećoj osobi nastala zbog obavljanja vatrogasne djelatnosti izravno odgovarati samo iznimno, kada je štetu počinio s namjerom. Osim trećoj osobi, vatrogasac za štetu počinjenu u sklopu vatrogasne intervencije može odgovarati regresno, u kojem slučaju je odgovornost šira te se odnosi i na štetne radnje uzrokovane krajnjom nepažnjom.

Novim Zakonom o vatrogastvu koji je na snagu stupio 1. siječnja 2020. godine detaljnije je regulirano pitanje odgovornosti za štetu nastalu u obavljanju vatrogasne djelatnosti. Uz pravnu regulaciju instituta nadoknade štete koja odgovara općem uređenju odgovornosti za nadoknadu štete, novim Zakonom o vatrogastvu učinjene su određene izmjene koje odgovaraju specifičnostima obavljanja vatrogasne djelatnosti.

Najznačajnija izmjena svakako se odnosi na proširenje odgovornosti za štetu nastalu u obavljanju vatrogasne službe na Republiku Hrvatsku, odnosno jedinice lokalne i područne samouprave, ovisno na kojoj razini vatrogasne intervencije je šteta počinjena.

Izričito navođenje primjene javnih ovlasti u provođenju vatrogasne intervencije kao razloga za oslobođenje odgovornosti svakako će otkloniti određene nedoumice u sudskoj praksi. Uz navedeno, novim Zakonom proširen je krug 
razloga za oslobođenje odgovornosti na štetu nastalu po nalogu nadređenog rukovoditelja ili zapovjednika te uzrokovanje štete krajnjom nepažnjom zbog znatnih napora u obavljanju vatrogasne djelatnosti, odnosno nastalu pod okolnostima kada je štetu bilo teško izbjeći.

Značajan pomak predstavlja i određivanje nadležnosti za odlučivanje o regresnoj odgovornosti vatrogasca o kojoj će biti odlučivano u stegovnom postupku u povodu teže povrede obveza iz radnog odnosa. Određivanje nadležnosti za odlučivanje o regresnoj odgovornosti u sklopu vatrogasnih organizacija svakako će pridonijeti uvažavanju svih specifičnosti obavIjanja vatrogasne djelatnosti u kontekstu mogućnosti uzrokovanja štete trećim osobama.

Nova regulacija svakako ostavlja i određena otvorena pitanja na koja će odgovor dati razvoj sudske prakse u navedenom području.

\section{LITERATURA}

Vedriš, M., Klarić, P.: Građansko pravo, Opći dio, stvarno, obvezno i nasljedno pravo, peto izdanje, Narodne novine, Zagreb 2001.

Zakon o obveznim odnosima, N.N., br. 35/05., 41/08., 125/11., 78/15., 29/18.

Zakon o trgovačkim društvima, N.N., br. 111/93., 34/99., 121/99., 52/00., 118/03., 107/07., 146/08., 137/09., 125/11., 152/11., 111/12., 68/13., 110/15., 40/19.

Zakona o udrugama, N.N., br. 74/14., 70/17., 98/19.

Zakon o ustanovama, N.N., 76/93., 29/97., 47/99., 35/08., 127/19.

Zakon o vatrogastvu, N.N., br. 125/19.

Zakono vatrogastvu, N.N., br. 106/99.,117/01., 36/02., 96/03., 139/04., 174/04., 38/09., 80/10.

\section{LIABILITY FOR DAMAGES DURING FIREFIGHTING INTERVENTIONS}

SUMMARY: Firefighting activities imply legal application of public authorisations when conducting firefighting interventions. Transgression of public authorisations or other illegal acts when performing firefighting activities can cause damages for third parties. Liability of fire brigades and firefighter organizations lies on establishing liability for damage caused by employees or their members. On the other hand, from the point of view of firefighters, liability for the damage caused when performing firefighting activities can be two-fold. The first includes damage liability a firefighter causes to third parties when performing firefighting activities. The second refers to the firefighter's responsibility for the damage caused intentionally or due to negligent conduct towards the Republic of Croatia or unit of local or regional administration, or damage to the firefighting station the firefighter works in or performs any related activities. The new Act on Firefighting, which came into force on 1st January, 2020 outlines in more detail the issue of liability for damage caused during performance of firefighting activities. This work investigates the legal base for damage liability within the scope of performing firefighting activities and the overview of amendments based on the new Act on Firefighting.

Key words: firefighting service, fire protection, compensation for damages, public authorisations 